\title{
PHYSICAL PROPERTIES AND MILLING QUALITY OF A NEW RICE DROUGHT VARIETY
}

\author{
Solaf S. Abd El-Raheam*
}

ABSTRACT

Some of the physical properties of the new rice drought variety (Sakha 107) in terms of principle dimensions (length, width, thickness), coefficient of contact surface and shape index- $k$ were measured and calculated at four levels of grain moisture content $(14.15,15.11,16.09$, and 18.04\%, w.b). The crack, head rice yield, broken grain percentages and whitening degree were also determined in term of milling quality at the same levels of grain moisture content and compared to the common rice variety Giza 177.

The results of this study showed that, length, width and thickness of the new rice drought variety (Sakha 107) increased linearly with the increasing of grain moisture content, while, shape index-k and coefficient of content surface decreased generally with the increasing of grain moisture content. For the rice milling quality, the head rice yield and degree of whitening increased with the decreasing of rice moisture content and the broken rice percentage increased with the increasing the rice moisture content for both rice varieties Sakha 107 and Giza 177.

In general, the data obtained from this study could help the designers and operators who deal with this new rice variety.

\section{INTRODUCTION}

ice crop provide a major source of calories for more than half of
the world's population; however, they also use more water than
other major crops (Carrijo et al, 2017). Water use efficiency studies have shown that approximately, $500 \mathrm{~L}$ of water is required to produce $1 \mathrm{~kg}$ of biomass (roots, stems, and leaves) in irrigated rice (Jodo, 1995). The yearly planted area of rice in Egypt is 685908 hectare (1.7 million feddan, FAO, 2017). The yield of this planted area almost meets the need of human consumption of rice. Unfortunately, nowadays, according to the shortage expected in irrigated water, this planted area is subject to drought stress.

\section{*Researcher, Agric. Eng. Res. Institute Dokki, Giza}


Manickavelu et al., 2006 reported that rice is one of the most important food crop drastically affected by drought and water deficit is one of the major environmental constraints severely reducing rice yields. Evenson et al. (1996) also mentioned that, the global rice yield loss due to drought was estimated to be 18 million tons or $4 \%$ of total rice production annually.

Therefore according to the shortage in irrigation water, the governorate started to reduce the rice planted area to meet the reduction in water available and it is desirable to breed new rice cultivars with improved drought tolerance. These cultivars should have almost the same yield and of course have a good quality of milled rice compared to the other cultivars that already planted in Egypt. So the researchers should pay attentions to evaluate the total yield and the quality of resulting white rice for these new varieties and studying the grain physical properties at different levels of grain moisture content presenting the rice grain at planting till processing. So care must be taken with breeding the new rice cultivars to keep the milling quality up parallel to the total yield.

Matouk et al. (1996) reported that, gradual increase in the degree of salinity of the irrigation water itself along the passage of irrigation channels represent a problem. This gradual increase in salinity of irrigation water may be due either to seepage of soil water to the lower parts of irrigation channel of to the reduced amount of water and hence increased salt concentration of the downstream portion of the irrigation channel. They also studied the effect of irrigation water salinity on milling characteristics of short grain rice varieties (Giza 172 and Giza 176) and reported that, crack percentage and grain hardness decreased with the increasing of irrigation water salinity. The objective in rice milling is to obtain the maximum possible percentage of whole kernels of white rice (head rice). The mechanical damage occurring in rice grains during the milling process depends not only on the milling machine design but also on the physical and varietal properties of rice (Radwan, 2001). There is also an important parameter affecting the broken percentage of rice grain, this parameter is the crack percentage of rice grains. Grain crack percentage affected with many parameters, such as plant history, drying methods, and milling methods. Matouk et al., 2004 reported that, grains principal dimensions, and grain projection area are generally 
increased linearly with the increasing of grain moisture content. While, the shape of grain (index-K) and coefficient of contact surface (C.C) are generally decreased with increasing of grain moisture content for all studied rice varieties and all levels of grain moisture content.

The objective of this study is to identify the new drought rice variety (Sakha 107) in terms of some physical properties (length, width, thickness), index-k and coefficient of contact surface at different grain moisture content. The milling quality was also studied and compared with the common rice variety Giza 177. The resulting data base could help the machine designers, engineers, and farmers who could deal with this new variety in planting, harvesting and processing.

\section{MATERIALS AND METHODS}

\section{$\underline{\text { Materials }}$}

New rice cultivar (Sakha 107) was used in this study representing rice drought varieties. The rice samples were obtained from Mansoura Agricultural Experiments Unit, Agricultural Research Center to grantee the purity of the variety. The experimental work of this study was carried out at Rice Mechanization Center, Meet El-Deeba, Kafr El-Sheakh Governorate and the Laboratory of the Agric. Eng. Dept., Faculty of Agric., Suez Canal Univ. The grain was cleaned to remove impurities, immature kernels and foreign materials and the moisture content of rice samples were determined. Then rice samples were stored in burlap sacks inside a ventilated storage room.

\section{Adjustment of different levels of grain moisture content}

Before the experiment, the stored grain was taken out of the burlap sacks and the initial moisture content was determined again. Then, the four desired moisture levels of rice were obtained by spread it on the concrete base with a layer thickness of $5 \mathrm{~cm}$. The moisture content was determined each four hours by using a KETT- moisture meter model (SP10) until reach the nearly desired four levels of moisture content. The grain samples then were sealed in separate polyethylene bags and stored in a refrigerator at around $-5^{\circ} \mathrm{C}$ to prevent moisture loss and fungal until the beginning of the experiment. Before each test, the required amount of grain for each test was taken out from the refrigerator and allowed to 
attain the normal room temperature. The moisture content of each sample was determined again before each test.

\section{METHODS}

\section{Measurements and Calculations}

\section{Grain moisture content (MC)}

The moisture content (MC) of rice grain samples was determined by the standard air oven method using air oven at $130{ }^{\circ} \mathrm{C}$ for $16 \mathrm{hr}$ (Matouk et al., 2002). The obtained moisture content was an average of three replicates and the grain moisture content was calculated in wet basis.

\section{Grain principal dimensions}

A digital caliper with accuracy of $0.01 \mathrm{~mm}$ was used to measure the length, width and thickness of 100 grain at each level of rice grain moisture content (Matouke et al., 2004).

\section{Coefficient of contact surface (C.C)}

Coefficient of contact surface (C.C) is considered an important parameter to determine the contact surface area between rice grains and machine parts especially rubber roller husker. It was calculated for different levels of rice moisture content according to (Abd Alla, 1995):

$$
C . C \%=\frac{F_{f}-T_{s}}{F_{f}} * 100
$$

Where:

$$
\begin{aligned}
& \mathrm{F}_{\mathrm{f}}=\text { area of oblong surface }=(\Pi / 4) * \mathrm{~L}^{*} \mathrm{~W}, \mathrm{~mm}^{2} \\
& \mathrm{~T}_{\mathrm{s}}=\text { area of transverse surface }=(\Pi / 4) * \mathrm{~W} * \mathrm{H}, \mathrm{mm}^{2}
\end{aligned}
$$

\section{Shape of grain (index-k)}

Grain shape (Index-k) was calculated using the measured values of the principal dimensions of rice grain samples and was used to describe shape of rice grain at different levels of grain moisture content using the following equation (Abd Alla, 1995):

$$
\text { Index }-k=L / \sqrt{(W . H)}
$$

Where:

$\mathrm{L}=$ length of rice grain, $\mathrm{mm}$.

$\mathrm{W}=$ width of rice grain, $\mathrm{mm}$.

$\mathrm{H}=$ thickness of rice grain, $\mathrm{mm}$. 
At shape index-k $>1.5$, the rice grain is considered oval but at shape index-k $<1.5$, the grain is considered spherical.

\section{Crack percentage measurement}

A total of 100 grain of rough rice sample was manually dehusked for each level of rice grain moisture content. The resulting brown rice was tested by using the reflection type crack meter (Fig.1).

\section{Grain hardness}

The grain hardness was measured for Sakha 107 and Giza 177 varieties. Few grains of rough rice, fairly uniform in shape, were selected and the hulls were removed by hand. The kernels were then visually inspected for cracks or other defects. Only sound, uniform, and uncracked grains were used for the test. Hardness of the rice grains in this study was tested using Hardness Tester \# 174886 Kiya Seisakusho, LTD (Fig. 2). Each grain was oriented on its flattest surface on the bottom plate, and the manual cross head was moved down until failure occurred. The hardness value of each sample was recorded in kilogram and converted as Newton (Radwan, 2001).

\section{Milling Tests.}

Milling tests were done to evaluate the quality of milled rice in terms of head rice yield, broken rice percentage and degree of whitening. Samples were passed through a Satake rubber roll model (THU 35A) with clearance adjusted to hull about $90 \%$ of the paddy in one pass (Fig. 3). The resulting brown rice was poured into the polishing chamber of the Satake miller (Fig. 4) which operated for $60 \mathrm{~s}$. All of the milled rice grains were carefully removed from the machine and collected in a pan and kept until it reached room temperature before sorting it to whole and broken kernels. Then the head rice yield and broken rice were calculated in percentages.

\section{Degree of whitening}

Degree of whitening of milled rice was measured by using a whiteness meter model C-300 (Fig.5).

\section{Statistical regression analysis:}

A simple regression analysis was applied to relate the change in grain dimensions, grain hardness, head rice yield, broken rice and degree of whitening with the change in rice grain moisture content. The general equation represented this relationship was in the following form:

$$
\mathbf{y}=\mathbf{a}-\mathbf{b x}
$$




\section{RESULTS AND DISCUSSION}

length, width, thickness, coefficient of contact surface and shape index-k were measured and calculated for the new rice drought variety (Sakha 107) at four levels of grain moisture content $(14.15,15.11,16.09$, and 18.04\%, w.b). The crack, head rice yield, broken grain percentage and whitening degree were also determined and measured in term of milling quality at the same levels of grain moisture content for new rice drought variety (Sakha 107) and the common rice variety (Giza 177).

\section{Grain principal dimensions (length, width and thickness)}

The measured principal dimensions of rice variety (Sakha 107) were varied for different rice grain moisture content under study. The effect of grain moisture content on grain principal dimensions is shown in figure 6 .

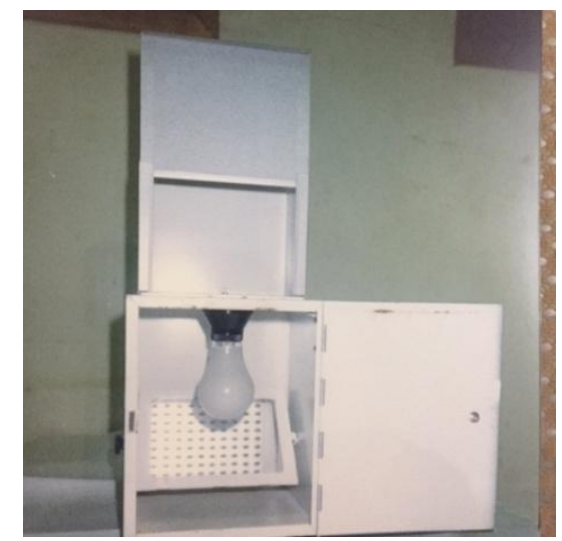

Fig.1: The reflection type crack meter

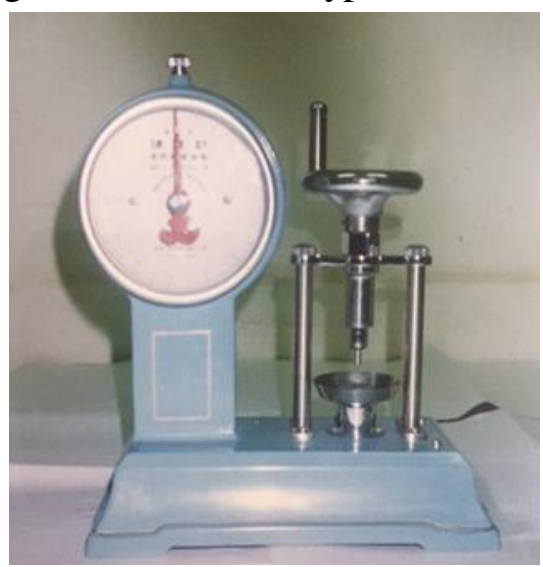

Fig. 2: Hardness Tester \# 174886 Kiya Seisakusho, LTD 


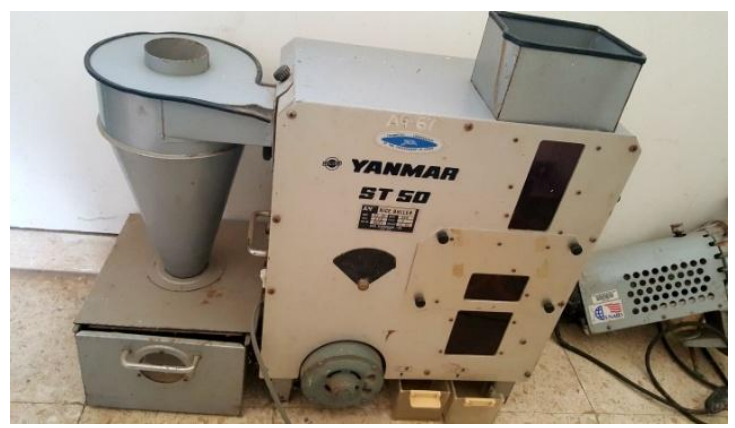

Fig.3: The Satake rubber roll model (THU 35A)

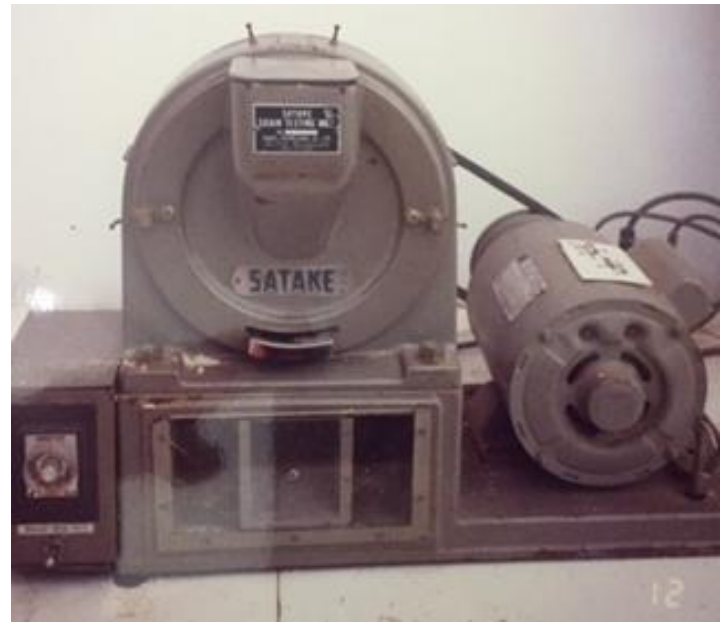

Fig.4: The Satake Whitening machine

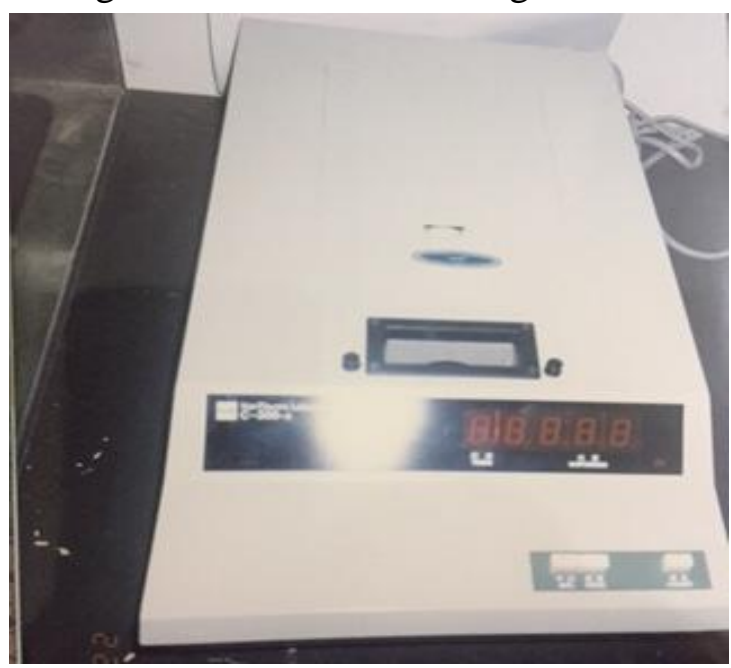

Fig.5: The whiteness meter model C-300 
As shown in the figure, the grain principal dimensions (length, width and thickness) increased linearly with the increasing of grain moisture content.

Length of rice grain increased from 7.37 to $7.49 \mathrm{~mm}$ with the increasing of grain moisture content from 14.15 to $18.04 \%$. On the other hand, the width increased from 3.30 to $3.39 \mathrm{~mm}$ with the increasing of grain moisture content from 14.15 to $18.04 \%$. While, thickness increased from 2.23 to $2.32 \mathrm{~mm}$ with the increasing of grain moisture content at the same levels. These data are so closed with that obtained from previous studies done by Matouk et al., 2004 for the common rice varieties in Egypt.

\section{Shape of grain (index-k)}

The calculated shape index-k for Sakha 107 variety at different levels of grain moisture content is presented in table (1). As shown in the table, shape index-k decreased generally with the increasing of grain moisture content. In general, shape index-k was more than 1.5 and this means that the rice grain (Sakha 107) is oval in shape.

\section{Coefficient of contact surface (C.C)}

The calculated coefficient of contact surface (C.C) for Sakha 107 variety at different levels of grain moisture content is presented in table (1). As shown in the table, the coefficient of content surface is generally decreased with the increasing of grain moisture content.

Table (1): Shape index-k and coefficient of contact surface (C.C) for rice variety (Sakha 107) at different levels of grain moisture content (M.C).

\begin{tabular}{|c|c|c|c|c|}
\hline M.C.,\% & $\mathrm{F}_{\mathrm{s}}$ & $\mathrm{T}_{\mathrm{s}}$ & C.C.,\% & $\begin{array}{c}\text { Shape } \\
\text { index-k }\end{array}$ \\
\hline 14.15 & 19.81 & 5.71 & 69.72 & 2.72 \\
\hline 15.11 & 20.12 & 5.86 & 69.41 & 2.7 \\
\hline 16.09 & 20.29 & 5.95 & 69.4 & 2.69 \\
\hline 18.04 & 20.59 & 6.08 & 69.04 & 2.67 \\
\hline
\end{tabular}

\section{Grain crack percentage}

Figure (7) shows the brown rice grain crack percentage at four levels of rice grain moisture content for both verities under the study. As shown in the figure, the crack percentages of rice grain increased slightly with the decreasing of rice grain moisture content. It can also noticed in the figure that, the crack percentage of grain variety of Sakha 107 was higher than that in grain variety of Giza 177, these results could be due to the drought 
conditions of the Sakha 107 variety in comparison with rice grain variety (Giza 177).
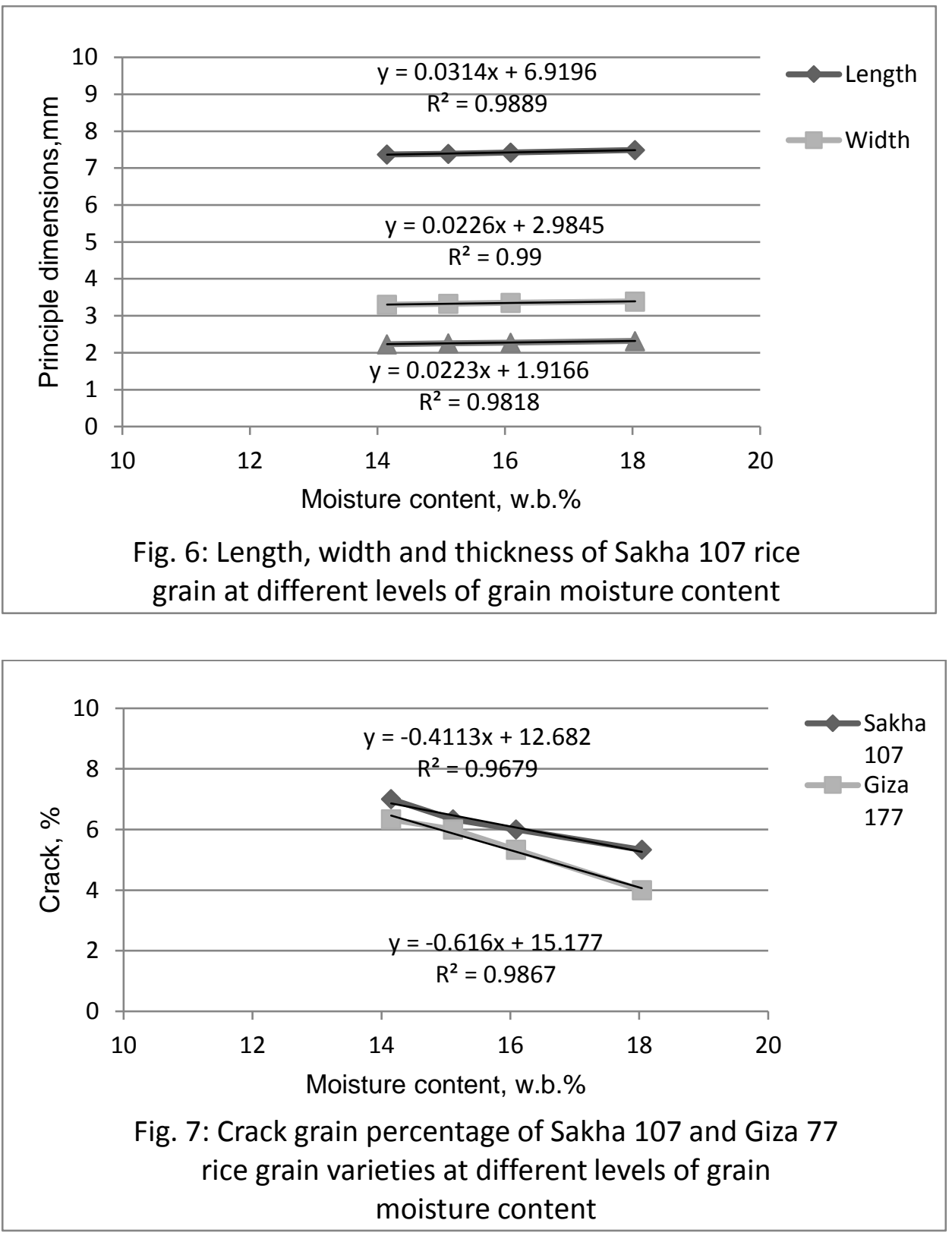

\section{Grain hardness}

Figure (8) illustrates the change in grain hardness as related to moisture content for Sakha 107 and Giza 177 varieties. As shown in the figure, 
grain hardness decreased with the increasing of grain moisture content for both varieties. On the other hand, Giza 177 variety recorded higher grain hardness in comparison with Sakha 107 variety. The recorded grain hardness was ranged from 32.37 to $38.26 \mathrm{~N}$ and from 30.67 to $37.28 \mathrm{~N}$ for Giza 177 and Sakha 107 varieties, respectively, for grain moister content levels of $(14.15,15.11,16.09$, and $18.04 \%$, w.b).

\section{Milled rice quality for Sakha 107 and Giza 177 rice varieties.}

Figure (9) presents the relationship between rice moisture content and head rice yield for Sakha 107 and Giza 177 rice varieties at different levels of grain moisture content. As shown in the figure, the head rice yield increased with the decreasing of rice moisture content. For instance, the recorded head rice yields for Sakha 107 variety were 59.12\%, 58.14\%, $57.11 \%$ and $55.25 \%$ for grain moister content levels of $(14.15,15.11$, 16.09 , and $18.04 \%$, w.b), while the corresponded head rice yield were $60.53 \%, 59.71 \%, 58.64 \%$ and $56.13 \%$ for rice variety (Giza 177) at same levels of rice grain moisture content.

Unlike the head rice yield, the broken rice percentage increased with the increasing the grain moisture content (Fig. 10). For instance, the recorded broken rice percentages for Sakha 107 variety were 10.36\%, 11.77\%, $13.77 \%$ and $15.44 \%$ for grain moister content of $(14.15,15.11,16.09$ and $18.04 \%$, w.b), while the corresponded broken rice percentage were $9.23 \%$, $10.15 \%, 12.34 \%$ and $14.33 \%$ at the same levels of grain moisture content for rice grain variety Giza 177. The reason that the rice variety Sakha 107 resulted in broken rice percentage slightly higher than rice variety Giza 177 could be due to the higher percentage in crack grain percentage and lower grain hardness for rice variety Sakha 107 compared to rice variety Giza 177.

Figure (11) shows the relationship between rice moisture content and degree of whitening for the two rice varieties under the study. As shown in the figure, the degree of whitening increased with the decreasing of rice moisture content for both varieties from 18.04 to $14.15 \%$. This reduction in degree of whitening may be due to higher contact between bran layers and kernel surface at higher grain moisture content. As shown in the figure, the recorded degrees of whitening were 40.9, 39.2, 38.7 and 38.2 for grain moister level of $(14.15,15.11,16.09$, and $18.04 \%$, w.b), while the 
corresponded degrees of whitening were 39.3, 38. 7, 37.7 and 37.4 for rice grain variety (Giza 177) at the same levels of grain moisture content. It can be said that, there was no difference in degree of whiting between both varieties under the study.
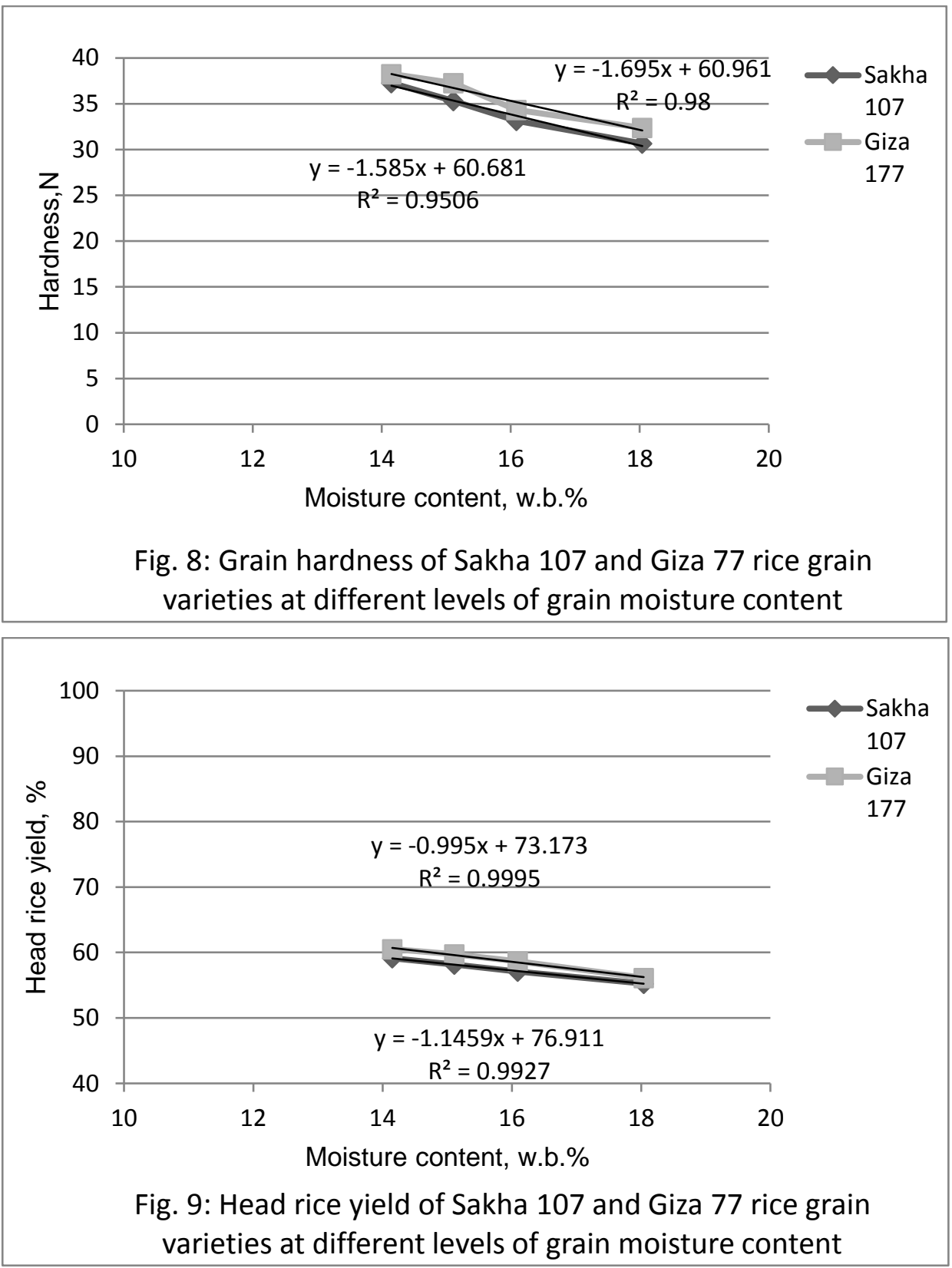

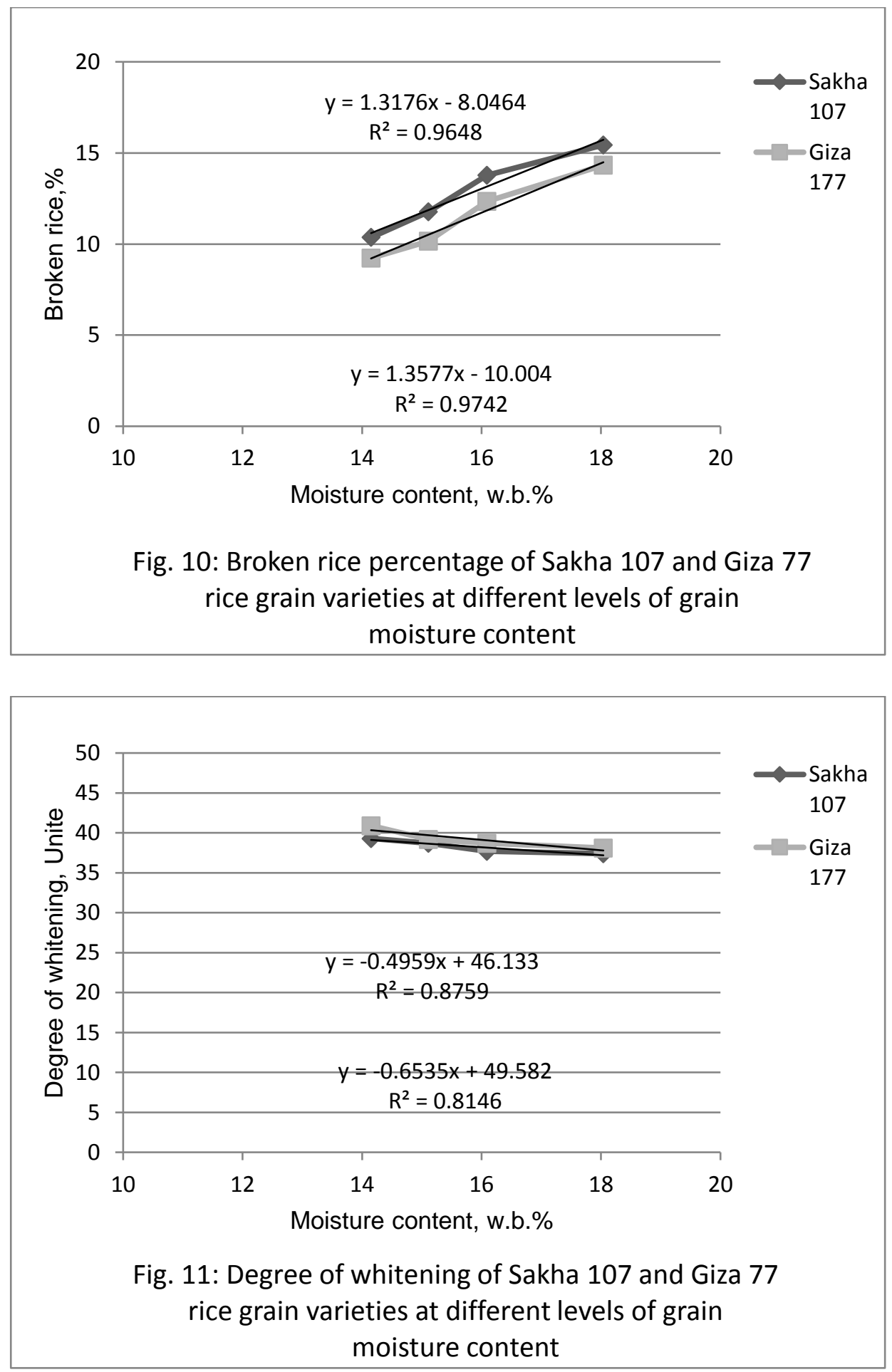
PROCESS ENGINEERING

\section{CONCLUSIONS}

1. Grains principal dimensions increased linearly with the increasing of grains moisture content for Sakha 107 rice variety.

2. Shape index-k decreased and coefficient of contact surface decreased with increasing of grain moisture content.

3. The data obtained from this study could help the designers and operators who deal with this new rice variety (Sakha 107).

4. The head rice yield increased with the decreasing of rice moisture content for the two varieties under study.

5. The broken rice percentage increased with the increasing of rice moisture content for the two varieties under study.

\section{REFERENCES}

Abd Alla, H.S.; S.M. Radwan and E.H. El-hanafy. 1995. Effect of some physical properties of rice grains on milling quality. Misr J. of Agric. Eng. Vol.12 No.1 143-155.

Carrijo, D. R.; M. E. Lundy and B. A. Linquist.2017. Rice yields and water use under alternate wetting and drying irrigation: A metaanalysis. Field Crops Research. V. 203, 1 March 2017, Pages 173-180

Evenson, R., Herdt, R. W., Hossain, M. 1996. Rice Research in Asia: Progress and Priorities, CAB International, Wallingford, UK.

FAO, 2017. Food and agriculture data.www.fao.org/faostat/ar

Jodo, S. 1995. In (Science of the Rice Plant. 2). Matsuo, T., Kumazawa, K., Ishii, R., Ishihara, K., Hirate, H. (Eds.), Physiology, Food and Agriculture Policy Research Center, Tokyo 1995, pp. 447-461.

Manickavelu A., N. Nadarajan, S. K. Ganesh, R. P. Gnanamalar and R. C. Babu. 2006. Drought tolerance in rice: morphological and molecular genetic consideration. Plant Growth Regulation (2006) 50:121-138.

Matouk, A.M., Y.M. El-Hadidi and S. M. Radwan. 1996. Effect of irrigation water salinity on milling characteristics of short grain rice. Misr J. Ag. Eng. V (13) N (2): 376-388.

Matouk, A. M.; S. M. Radwan; A. Hamam; M. M. EL-Kholy and T. R. Ewies 2002. Study of the physical properties and 
characteristics of some agricultural crops for developing and designing harvesting and handling equipment and systems (grain crops). Final report of the Proj. Sci. Res. and Tech. Acad. Egypt.

Matouk, A. M. ; S.M. Radwan; A. Hamam; M. M. El-kholy and T. R. Ewies.2004. Study on fundamental physical properties and characteristics of some cereal crops. Misr J. Ag. Eng. V (21) N (3): 376-388.

Radwan S.M. 2001. The potential energy consumption for milling some Egyptian rice varieties. Misr J. Agric. Eng. Vol. (18) No (3): 537551

الملخص العربي

الخواص الطبيعية ومواصفات الضرب لصنف الأرز الجديد المقاوم للجفاف

\section{سلاف سيد عبد الرحيم علي*}

يعثبر محصول الارز مصدر الطاقة الاساسى لاكثر من نصف سكان العالم وخاصة مصر حيث

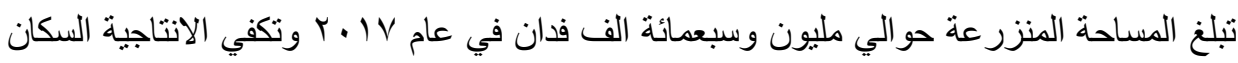

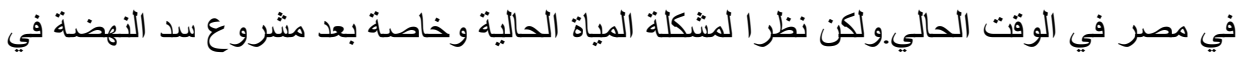

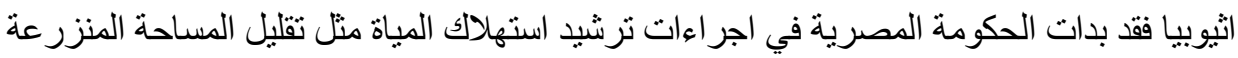

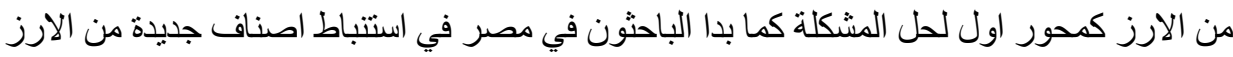

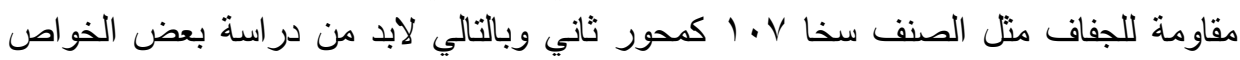

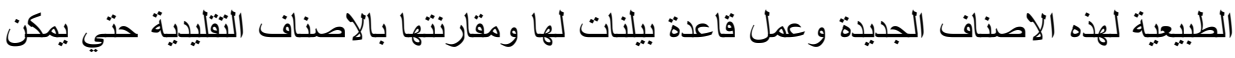

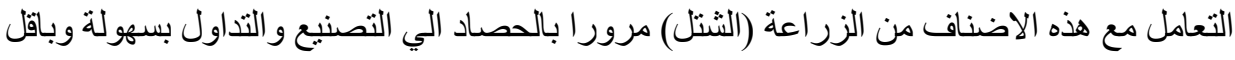

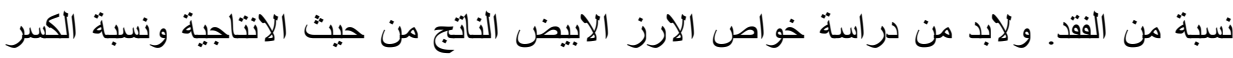

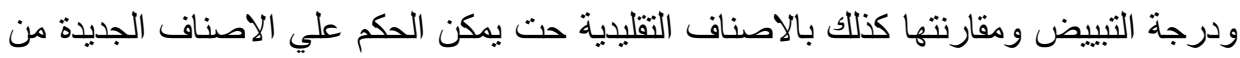

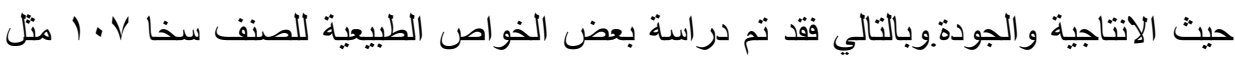

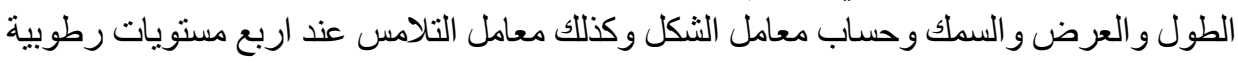

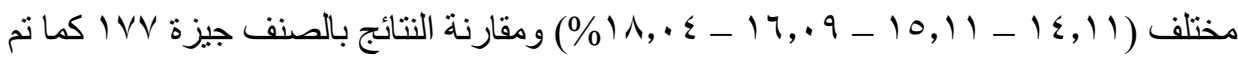
دراسة ايضا خواص الضرب للصنف الجديد مثل نسبة الحبوب السليمة ونسبة الكسر ودرجة التبييض.

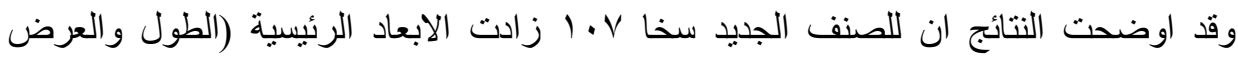

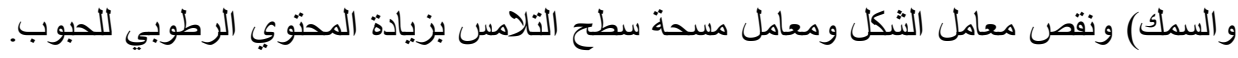

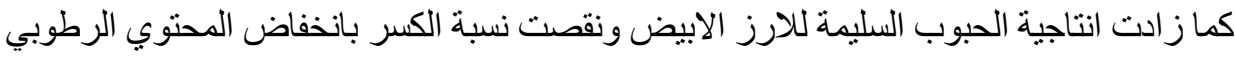
ونقصت درجة التبييض بزيادة المحتوي الرطوبي للحبوب وكانت النتائج مقاربة للاصناف التافيض التقليدية

(جيزة) (IVV)

$$
\text { باحث ـ معهة بحوث الهندة الزراعية ـ الدقي - الجيزة. }
$$

